\author{
ELENA VLADIMIROVNA MALYSHKINA ${ }^{1}$ \\ OLGA NiKOLAEVNA GOROSHKO ${ }^{2}$ \\ FEDERAL AUTONOMOUS EDUCATIONAL INSTITUTION OF HigheR EDUCATION \\ "North-CAucasus Federal University", The InSTITUTE of SeRVICE, \\ TOURISM AND DESIGN (BRANCH OF NCFU) IN PYATIGORSK \\ IRINA ALEKSEEVNA BONDAR ${ }^{3}$ \\ StAVRopol State Pedagogical InStitute, \\ DePARTMENT OF History, PHILOSOPHY AND SOCIAL SCIENCES \\ JORDAN P. GORČEV 4 \\ THE INTERNATIONAL SLAVIC UNIVERSITY “GAVRILO Romanovich DeRZHAVIN”, \\ FACULTY OF ECONOMICS, DEPARTMENT OF HISTORY
}

\title{
HISTORICAL REVIEW OF RUSSIAN NATIONAL POLICY IN THE NORTH CAUCASUS
}

\begin{abstract}
In this article, the authors tried to trace in a wide historical and ethno-political context of the development of Russian national policy exemplified by the republics of the North Caucasus at different time stages, having done so on the basis of the most representative range of sources. Comprehended in the historical dynamics of domestic and international experience, special attention is paid to those items that can be used to develop the foundations of the national policy of the Russian Federation in the North Caucasus at the present stage. In this regard, new aspects and provisions have been identified in the following areas: Russian (imperial and Soviet) experience in managing the North Caucasus region; the impact of changes in nation-building on the ethno political processes in the region; ethno political processes in the post-Soviet period and features of their manifestation in the republics of the North Caucasus; modern political processes in the North Caucasus in the context of Russian federalism; main problems and
\end{abstract}

\footnotetext{
soft_25@mail.ru

goroshko_olenka@mail.ru

sloikin89@rambler.ru

msisvnikole@yahoo.com;
}

This paper was submitted on May $11^{\text {th }}, 2019$ and accepted for publication at the meeting of the Editorial Board held on September $16^{\text {th }}, 2019$. 
the contradictions of the Russian model of federalism; the experience of state authorities in the regulation of inter-ethnic relations in the region; possible scenarios for the development of federative relations in Russia and ways to optimize them are presented.

KEYWORDS: national relations, national policy, ethno political processes.

\section{INTRODUCTION}

In the new conditions of Russia in the 1990s and the beginning of the XXI century, it became possible to develop new "models" of solving the problems of the development and improvement of ethnic communities. National relations in the Russian Federation have become an integral part of the state national policy. Many provisions in this direction were translated into practical terms. Their decision largely determines the course of social development. All this underlines the thesis-a national idea, capturing the minds, is capable of giving a powerful impetus to the progressive processes. Truth, although often exploited in order to gain power, is used to incite ethnic hatred and serves as a justification for separatism. In this situation, the task of the state national policy is to contribute in every way to the development of ethnic communities in Russia, their consolidation within the framework of a single state.

\section{METHODOLOGY}

In order to elaborate on the topic, the principles of a comparative analysis of the period under study with earlier periods of the history of Russian society, as well as historical and methodological analysis of Russian policy from the second half of the 19th century until 1990 in the field of national relations, are applied. All this allowed a consideration of the process of national relations in evolution and in a broader chronological framework.

For purposes of the theoretical research, we relied on the work of scientists, containing materials related to the problems of interethnic relations. In these works, special attention was paid to the issues of overcoming the socio-economic underdevelopment of the ethnic communities of the North Caucasus and the evolution of their national statehood. 
We studied the articles of the authors who have devoted their research to the problems related to interethnic relations in the North Caucasus, of which we cite the most vivid examples, as well as historical references. The study benefited from the publications edited by S.I. Samygin, A.V. Vereshchagin, M.T. Belov (2015). Definite help in covering the issues of legal regulation of international relations in the Russian Federation gave came from the authors such as F.I. Valyarovsky, N.L. Didenko, L.A. Sugrey, etc (2011). Among other works which consider the problems of emigration, we can name A.I. Magomeddadaev (2001).

\section{MAIN PART AND DISCUSSION}

The orientation of the national policy of the Soviet state differed significantly at different stages of history. It is impossible not to recognize the fact that during the years of the Soviet power, the gap in the economic situation of ethnic communities was noticeably reduced, their educational and cultural potential increased, and the layer of common cultural values was formed, and rich experience of cooperation of ethnic communities was accumulated. But one must not keep silent about the fact that there was an excessively rigid centralism, ideological dictatorship, which leveled cultural diversity. Against the general background of achievements in these conditions-it was then recognized as socialism under construction-serious mistakes were made in the state national policy. Political repression, including the deportation of the public, the application of voluntaristic principles in economic development, and ill-conceived migration policies led to the 1980s and 1990s aggravation of ethno-social and ethno-demographic problems.

A largely declarative national policy had no mechanisms for regulating interethnic relations. The system of national-state structure, the hierarchy of the political and legal status and the practice of nationalizing the nationality of citizens, adopted into armament, came into conflict with the realities of life.

After the proclamation of the state sovereignty of the Russian Federation, the federal bodies of state power adopted political and legal documents on the issues of national policy, interethnic relations, on the basis of which the construction of national sovereignties was carried out in the Russian state. Previously adopted criminal and unjustified acts were abolished and sovereign rights 
of national and regional entities were recognized. In March 1992, a federal agreement was signed on the delimitation of authority between the federal and state authority of the subjects of the Russian Federation.

At the same time, there was a serious delay with the elaboration of directions of the state national policy, the creation of a legislative framework for the regulation of interethnic relations. An incorrect assessment of the nature, depth, and scale of national processes in the territory of the Federation itself prevailed.

The increase in tension in this area was considered mainly as a consequence of the resistance of the remnants of the former regime. Some laws that have already been adopted in the sphere of national policy turned out to be thoughtless.

The crisis of inter-ethnic relations in the Russian Federation in the 1990s, which was a consequence of the state of the society as a whole, had its own reasons. Its objective essence was dramatically exacerbated at a crucial stage in the development of the country contradictions:

- between the growing desire of nations for intra-national consolidation and the process of integration of society, which has its own socio-economic conditions;

- between the sovereignty of parts of the federation and the objective need to preserve and strengthen the interests of all the peoples of the all-Russian statehood;

- between the specific interests of peoples that have emerged in the course of democratic reforms and the need for a mutual search for compromises in their implementation;

- between the need for coordinated implementation of economic and political reforms on the territory of a federal state and the presence of significant differences in the conditions of socio-economic development of the regions, as well as their readiness for transformations (Tishkov, 1999).

These factors exacerbated the situation in the state. The legacy of the past-the geopolitical and psychological consequences of the collapse of the USSR and the socio-economic and political difficulties of the transition period-led to the emergence of crises and conflicts in the field of interethnic relations.

They were most acute in the North Caucasus, which is distinguished by its multi-ethnic and multi-religious nature. The ethno political situation in the region was affected by persistent hotbeds 
of bloody armed conflicts and their consequences (Chechen, Ossetian-Ingush, Georgian-Abkhazian, Georgian-South Ossetian, Karabakh), which turned the Caucasus into an unstable region. This, of course, had a negative impact not only on the adjacent, but also on the far regions of Russia. Conflicts, armed clashes, destruction, hostage situations, terrorism, and violence have created a moral-psychological syndrome of mutual alienation, hatred, and enmity, which are not typical of Russian people.

Against this background, the radical nationalist organizations of the North Caucasus actively began to undertake attempts to implement various forms of self-determination that threaten the state unity and the territorial integrity of the Russian Federation. Proclaimed slogans asking for:

- secession from the Russian Federation (Chechen Republic);

- the division or internal federalization of republics on a national basis (Republic of Dagestan, Kabardino-Balkaria Republic, Karachay-Cherkessia Republic);

- changes in the boundaries of the subjects of the federation due to the separation of areas of compact residence of individual ethnic communities, with the aim of creating their own statehood or autonomy (for example, the Terek Cossacks, Kumyks, Balkars, Kabardians, Nogai, Shapsugs, Lezgins).

Simultaneously with the growth of tension at the inter-ethnic level, the unifying tendency at the ethno regional level (Abazins, Ossetians, Lezgins, Circassians, Chechens, Nogays and others) intensified. The processes associated with the consolidation of the resurgent Cossacks intensified (Keldasov, 1999).

The collapse of the USSR led to the transformation of the administrative-territorial borders with the Transcaucasian republics in the state. This gave rise to the acute question of "divided people" (Lezgins, Avars, Adygs, Ossetians, Tsakhurs, Azeris, etc.) (Cheshko, 1996).

The unresolved problems of borders, the difficulties associated with ensuring the freedom of communication for representatives of "divided people" transformed this problem into a political one, dramatically increasing the potential of ethnic conflict, which had a negative impact on the sphere of interstate relations (Kurbanov \& Yusupova, 1996).

The high level of politicization of society and the presence of a multitude of national, religious parties and movements that sought 
to compete with state authorities for the selection of priorities for national-state development, revived the tendencies of all-Caucasian political association and the construction of a confederative state of the Caucasian peoples independent of Russia (mountaineers of the Caucasus).

Despite the seemingly unifying character, this idea gave rise to a policy directly opposed to the objective needs of the integration of people and territories of the North Caucasus region. The attempt to integrate the Caucasus on anti-Russian slogans led in practice only to a break of centuries old and established economic, cultural, and personal ties in this region, stimulating the struggle for the redistribution of the geopolitical heritage of the Russian state, interference in the internal affairs of Russia by the international financial and industrial groups, and the foreign powers behind them.

At the same time, the process of developing inter-ethnic relations, especially in the early 1990s, was increasingly ideologized. Numerous organizations based on ethnic and religious basis were increasingly active in the region. At the same time, militant nationalism and ethnocentrism, religious sectarianism, as a rule, were decisive in their ideology. Some of these organizations put forward claims for monopoly representation in the political life, trying to simultaneously assume power functions (or dictate terms to the authorities) while relying on armed national formations in the political struggle (Leksin \& Shvetsov, 2000).

Obviously a real threat to interethnic harmony is represented by the active penetration of Wahhabism, the assertion of the non-traditional for the North Caucasus distorted Islam norms in individual republics of the region. On this basis, Muslim and interfaith confrontations often flared up.

National-ethnic and religious ideas in the region are often used for mercenary purposes. And often they are played not only by the leaders of opposition movements but also under their influence by the forces in power. Most of the conflicts in the North Caucasus, which are based on political, legal, economic, and territorial contradictions, developed taking the form of ethno-political or purely ethnic conflicts. In turn, interethnic contradictions in such cases tend to politicize transition to the plane of relations between the subjects of the Federation or between the subject of the Federation and the Federation itself.

The protracted economic, social, and environmental crisis experienced by the North Caucasus has a negative impact on the ethno 
political situation, as a result and consequence of the all-Russian crisis and disintegration, the rupture of economic ties, and the low efficiency of the reforms being carried out in the country. The North Caucasus region in modern conditions is almost subsidized. The decline in production and, as a consequence, the decline in the standard of living of the majority of citizens, a significant gap in the levels of socio-economic development of the republics, territories and regions is in itself a significant factor in the aggravation of both inter-ethnic relations and relations between the subjects of the Federation, as well as in Federation itself. All this gives rise to the desire to subordinate resources, finance, and to gain access to key posts in the management of the economy. Ultimately, such actions become the breeding ground for the growth of corruption and the criminalization of society, which often acquire a pronounced ethnic tint.

Definitely, a sharp violation of the well-established diverse ethnic, ethno-cultural, and confessional structure, habitual way of life occurs in conditions of an extremely high level of external and internal migration, generated by conflicts in Central Asia, Transcaucasia, in the North Caucasus itself. In conditions of high population density, lack of land in mountainous areas, low living standards, exacerbation of social problems, all this carries a dangerous charge of instability. The situation was also aggravated by the historical insult on the repressive policy of tsarism and the Stalin regime that remained in the memory of the people. The consequences of the ill-conceived resettlement policy were pursued by both the Russian empire and the Soviet authorities, the numerous redrawing of administrative borders, without taking into account the historically established territories of the North Caucasus also had an effect. The forcible resettlement of some people in the territories from which others were evicted-deported, repressed people-gave rise to interethnic territorial disputes, exacerbated tensions between the "autochthonous" and "migrants", the Russian Cossacks and the mountain people of the North Caucasus (Mikhailov, 1995).

The situation in the North Caucasus is particularly acute because of the unresolved problems associated with the Chechen crisis. It also plays a decisive role in the growth of crime, especially in such serious manifestations as terrorism, kidnapping, and violent acts against the population of adjacent regions. The evidence of this was the next foray of religious extremists in October 2005 in Nalchik, 
when the institutions of the KBR power structures were attacked. As a result, innocent civilians, law enforcement officers died.

The concept of the state national policy of Russia, approved by Decree of the President of the Russian Federation on June 15, 1996, created favorable conditions for the stabilization of the ethno-political situation in the North Caucasus. In the framework of the Concept the federal center and government bodies of the republics of the North Caucasus implemented a series of inter-ethnic regulation and improvement measures for federative relations in the early XXI century. It can be argued that 2000 clearly shows a trend towards social and political stabilization.

The growth of general organization and effectiveness of management measures is evident not only in actions of public authorities and local self-government, but also in the actions of various public political parties and movements.

At the same time, the ongoing economic recession exacerbated social problems that not only remained unresolved, but also "organized" and acquired systemic nature, national-territorial conflicts have noticeably become aggravated. The essence of the overwhelming majority of these conflicts was that one and the same territory turned out to be a space where rival national elites sought to achieve their legal domination involving access to political power and prestigious sectors of the economy. Wherein all attempts to "raise the shield" problems of disputed territories carried the potential danger of a latent stage transition conflict into an open armed, with the exacerbation of public political situation in the entire North Caucasus and Transcaucasia (Kukushkin \& Barsenkov, 1992).

Among the causes of the ongoing crisis of inter-ethnic relations in the North Caucasus lack of the realistic, comprehensively justified state national policy is far from the last. There is no system established on the state level, weighted and free from the stereotypes common in the past with reference to national problems, nor is there a reliable norm in scientific analyses and forecasts that takes into account the public opinion.

All this contributed to the fact that the sphere of national relations was analyzed directly by the President of the Russian Federation at the World Congress of Tatars in Kazan in August, 2002. At the end of 2002, an instruction was given to introduce amendments to the Concept of the state national policy of the Russian Federation. However, a change in the structure of the Government of the Rus- 
sian Federation did not allow implementing the instructions immediately. It was only on December 31, 2004, that the Government of the Russian Federation expressed the need to prepare such amendments. These tasks have been completed. After extensive discussion in September 2005, the draft Concept, as amended, was submitted for consideration by the Government of the Russian Federation (Resolution of the Government of the Russian Federation, 2005).

Many theoretical aspects of the problem were developed in Annual Address of the President of the Russian Federation, V.V. Putin, at the Federal Assembly of the Russian Federation. It was in 2003 that more attention was focused on the necessity of "preserving the integrity of the Russian state", "retaining the state over a wide area, preserving a unique community of nations with the country's strong positions in the world" (Message of the President of the Russian Federation to the Federal Assembly, 2003). The implementation of the priority tasks in the socio-economic sphere to a greater degree to the society, to the problems of national relations, and to the role of the national factor in addressing the issue of internal boundaries between subjects of the Russian Federation was also emphasized.

In our opinion, this ideological installation must certainly be transformed from practice (interethnic conflict) into theory when shaping the new consciousness of citizens in relation to the concept of "internal borders". The President notes on this issue: "And finally, free and fair society has no internal boundaries restrictions on movement, and it is itself open to the rest of the world. This gives the citizens of our country the opportunity to enjoy the riches of human civilization fully, including achievements of education, science, world history and culture" (Message of the President of the Russian Federation to the Federal Assembly, 2005). In theoretical terms, the presentation of the problem of the role and place of national factors represent the value of the annual address from the presidents of the republics of the North Caucasus to parliament of the republics. So, the President of the Kabardino-Balkaria Republic V.M. Kokov, addressing the Parliament of the Republic (2003) along with information on the state of the economy, industrial, and agricultural sector-paid attention to the analysis of social problems, specifically relations between people inhabiting the republic, the role and place of the national factor in folding and development of the Institute of Civil Society. 
V.M. Kokov (2005) urged not to allow "the separation of our people into groups by political predilections, we have to do everything you need to maintain our level of consolidation of the society".

In terms of analyzing the role and place of the national factor in the system of public relations, numerous parliamentary seminars and hearings were held. Special interest is raised by those who were devoted to the situation in national relations. One of such events was for example, a seminar-meeting of chairmen of committees (commission) of the legislative bodies of the subjects of the Russian Federation (Moscow, March 30, 1998). During the seminar, the Concept of the State National Policy of the Russian Federation was specially considered. Special emphasis was put on the formation of new Russian federalism, the need to have a clear definition of the place and role of the Russian people in this process, the adoption of regulations for the rehabilitation of people, overcoming the consequences of the Ossetian-Ingush conflict, etc.

Many other committees of the State Duma of the Russian Federation also focused on the situation in the field of national relations. Therefore, in April 1996 the federations held parliamentary hearings on the topic: "On the practice of delimitation of competences and powers between federal government agencies and bodies of state authority of the subjects of the Russian Federation and prospects of development of Russian federalism", where deputies of the State Duma, representatives of subjects of the Russian Federation, and scientists discussed the issue (1996).

The analysis showed that to preserve the unity and territorial integrity of the Russian Federation the unity of its legal and economic space need to clearly outline the terms of reference of the federal government bodies, which, on the one hand, must reliably provide protection of national interests, and on the other hand, based on the principle of equality of subjects, take into account the specifics of each reference.

Thus, the problems of national policy and regulation of national processes in the North Caucasus are one of the most pressing in historical science and are of great practical importance in terms of developing a mechanism for their implementation.

CONCLUSION Changes in the Russian society and the formation of national identity contribute to a marked transition from the imperial study of social phenomena of the spiritual and material sphere of any phenomena to the historical dynamics in relations to the other phe- 
nomena. Such approaches are characteristic of the 1990s and the beginning of the XXI century. This is due to the fact that there is a constant need to systematize and summarize the materials of the socio-economic history, history of national relations and policy in relation to "foreigners" until 1917 and in subsequent years. This is the way to show the connection between nations through their history and culture, its diversity. The use of both the formational and civilizational approach contributed to a deeper analysis of the national processes. Along with this, historical comparative methods are used in the consideration of historical processes, events, and phenomena, taking place in the life of the Russian state and the life of the nations. In assessing past events (until 1917), in the Soviet period of history, the authors appealed to the principle of objectivity, content analysis method, general scientific, and historical ethnographic methods. standing of the situation in the field of national relations, shaping the worldview and national identity. Therefore, it will identify many theoretical provisions for predicting the development of national relations in the Russian society, development and adoption of real concepts in different areas of national politics.

Examining the results of the investigation, availability of published sources, identification of archival materials, and especially the current archives of ministries and departments, publications of the press, and periodicals allowed to present a comprehensive study on the issues of inter-ethnic relations in the republics of the North Caucasus in one of the difficult periods of their history in terms of independent existence from Russia, which has chosen the path of its development as a rule of law being built on civilizational principles.

THANKS We express our gratitude to the funds of the State Archive of the Russian Federation: F-R 235, 4085, 1318, 4085; Central State Archive of the Republic of Dagestan: F-R 352, 168; Documentation Center of the recent history of Kabardino-Balkaria Republic (F. 2599; F. 2610); National Archives of Adige Republic: F-R 499; State of the archive of the Karachay-Cherkessia Republic: F. 898, 942.

We would like to thank our colleagues who are not the authors of the article, but with their assistance the study was conducted: T.V. Mykhortova, Associate Professor of the Chair of Linguistics and 
Intercultural Communication, and G.N. Rykun, Doctor of Historical Sciences, Professor.

We also express our gratitude to E. M. Shevchenko, Associate Professor of the Chair of Linguistics and Intercultural Communication, for valuable advice in planning the research and recommendations on the article.

REFERENCES Cheshko, S. V. (1996). The decay of the Soviet Union: an ethno political analysis. New science: problems and prospects, 4, 18-34.

Keldasov, R. B. (1999). Noghais: past, present and problems. People of Dagestan, 2, 38-44.

Kukushkin B. S. \& Barsenkov A. S. (1992). To the question of the concept of national policy of the Russian Federations. Ethnopolis, 9-12.

Kurbanov M.R. \& Yusupova G. I. (1996). Lezgins: the problems of divided people. People of Dagestan, 2,113-118.

Leksin V. N. \& Shvetsov A. N., (2000). Theory and practice of the state regulation development. State and regions, 1, 368-387.

Magomeddadaev, A. I. (2001). Emigration. Dagestan, the Ottoman Empire. Modern concepts of science development, 1, 68-75.

Message of the President of the Russian Federation to the Federal Assembly "Message of the President of Russia Vladimir Putin to the Federal Assembly of the Russian Federation", Russian newspaper, May 17th 2003, no. 3210, Moscow, p. 2-6.

Message of the President of the Russian Federation to the Federal Assembly "Message of the President of Russia Vladimir Putin to the Federal Assembly of the Russian Federation", Russian newspaper, April 26th 2005, no. 3755, Moscow, p. 3-5.

Mikhailov V. A. (1995). National policy as a factor of the state construction. Patterns and trends in the development of science in modern society, 3, 61-68.

On the practice of separation the power between federal government and public authorities of the constituent entities of the Russian Federation and prospects of development of Russian federalism (1996). Collection of laws of the Russian Federation, Moscow, Art. 898, p. 35-40.

Resolution of the Government of the Russian Federation (January 26, 2005). "On Approval of the Regulations on the Ministry of Regional Development in the Russian Federation and on Amendments to Certain Acts of the Government of the Russian Federation". Collection of the Law of the Russian Federation, 2004, no. 49, Art. 4889.

Samygin, S. I., Vereshchagin, A. V., Belov, M. T. (2015). Threats of national identity in the information space of modern society and information security risks. Economic and humanities research areas, 4, 78-85. 
Tishkov, V. A. (1999). Ways of peace in the North Caucasus, independent expert report. Moscow: Aviaizdat. p. 33-42.

Valyarovsky, F. I., Didenko, N. L., Sugrey, L. A. (2011). Actual problems of legal regulation of international relations in the Russian Federation. New science: strategies and vectors of development, 113-120.

\author{
ЕЛЕНА ВЛАДИМИРОВНА МАЛЫШКИНА \\ ОЛЬГА НИКОЛАЕВНА ГОРОШКО \\ ФЕДЕРАЛНИ УНИВЕРЗИТЕТ СЕВЕРНОГ КАВКАЗА У ПЈАТИГОРСКУ \\ ФАКУЛТЕТ ЗА УСЛУЖНЕ ДЕЛАТНОСТИ, ТУРИЗАМ И ДИЗАЈН \\ ШКОЛА КАВКАСКОГ ГОСТОПРИМСТВА \\ КАТЕДРА ЗА ЛИНГВИСТИКУ И ИНТЕРКУЛТУРНУ КОМУНИКАЦИЈУ \\ ИРИНА АЛЕКСЕЕВНА БОНДАРЬ \\ СТАВРОПОЛСКИ ДРЖАВНИ ПЕДАГОШКИ УНИВЕРЗИТЕТ (ОДЕЉЕњЕ У ЈЕСЕНТУКИ) \\ КАТЕДРА ЗА ИСТОРИЈУ, ФИЛОЗОФИЈУ И ДРУШТВЕНЕ НАУКЕ \\ ЈОРДАН П. ГОРЧЕВ \\ МЕБУНАРОДНИ СЛОВЕНСКИ УНИВЕРЗИТЕТ „ГАВРИЛО РОМАНОВИЧ ДЕРЖАВИН“ \\ ЕКОНОМСКИ ФАКУЛТЕТ, КАТЕДРА ЗА ИСТОРИЈУ
}

РЕЗИМЕ

ИСТОРИЈСКИ ПРЕГЛЕД РУСКЕ НАЦИОНАЛНЕ ПОЛИТИКЕ

\title{
У СЕВЕРНОМ КАВКАЗУ
}

У овом чланку аутори су покушали да прате развој руске националне политике у широком историјском и етно-политичком контексту користећи пример република Северног Кавказа у различним временским фазама, на основу најрепрезентативнијег спектра извора.

Разумљиво, у историјској динамици домаћег и међународног искуства посебна пажња се посвећује лекцијама које се могу користити за развој темеља националне политике Руске Федерације у Северном Кавказу у садашњој фази. У вези с тим, идентификовани су нови аспекти и одредбе у следећим областима: руско (империјално и совјетско) искуство у управљању подручјем Северног Кавказа; утицај промена у национално-државној изградњи у односу на етно-политичке процесе у региону; етно-политички процеси у пост-совјетском периоду и карактеристике њихове манифестације у републикама Северног Кавказа; савремени политички процеси Северног Кавказа у контексту руског федерализма; главни проблеми и контрадикције руског модела федерализма; искуства државних власти у регулисању међуетничких односа у региону и презентовани су могући сце- 
нарији за развој федеративних односа у Русији и начин њиховог оптимизовања.

У новим условима Русије деведесетих - почетак XXI века, појавила се могућност развоја нових „модела“ у решавању проблема развоја и унапређивању етничких заједница. Национални односи у Руској Федерацији постали су саставни део државне националне политике. Многе одредбе у овом правцу преведене су у практичне оквире.

Њихова одлука у великој мери одређује ток социјалног развоjа. Све ово наглашава тезу - да национална идеја може дати снажан подстрек прогресивним процесима. Ова идеја је често експлоатисана да се добије моћ, користи се за подстицање етничке мржње и служи за оправдавање сепаратизма. У овој ситуацији, задатак државне националне политике је промовисање развоја етничких заједница у Русији и њихова консолидација у једној држави.

Са циљем да се открије тема која се проучава, примењују се принципи компаративне анализе периода који се проучавао у претходним периодима историје руског друштва, као и историјска и методолошка анализа руске политике из друге половине XIX века у области националних односа. Ово је омогућило да се размотри процес националних односа у еволуцији и у ширем хронолошком оквиру.

Оријентација националне политике Совјетске државе значајно се разликовала у различитим фазама историје. Немогуће је не признати чињеницу да се током година совјетске власти процеп у економској ситуацији етничких заједница значајно смањио, увећао се њихов образовни и културни потенцијал, створен је слој заједничких културних вредности, акумулирано богато искуство сарадње етничких заједница. Међутим, немогуће је прећутати чињеницу да је било превише строгог централизма, идеолошке диктатуре, који су поравнали културну разноликост. Насупрот позадине постигнућа независности у условима изградње социјализма, у државној националној политици направљене су озбиљне грешке и деформације. Политичке репресије, укључујући депортацију народа, примена волонтерских принципа економског развоја, лоше осмишљене миграционе политике довели су до периода 1980-1990-их и до погоршања етно-социјалних и етно-демографских проблема.

У великој мери декларативна национална политика није имала механизме да регулишу међуетничке односе. Систем нацио- 
налне државности, хијерархије политичког и правног статуса и праксу национализације националности држављанства грађана, довели су до сукоба са реалностима живота.

Промене у руском друштву и формирање националног идентитета доприносе значајној транзицији друштвених научника од царског проучавања друштвених феномена духовне и материјалне сфере, свих феномена историјске динамике и односа са другим феноменима. Такви приступи карактеристични су за 1990-е и почетак XXI века. То је због чињенице да постоји стална потреба за систематизацијом и генерализацијом материјала из социо-економске историје, историје националних односа и политике у однос према „странцима“ пре 1917. године и у наредним годинама. Ово је начин да се покаже веза између нација кроз њихову историју и културу и њену разноликост. Коришћење формацијског и цивилизацијског приступа допринели су дубљој анализи националних процеса.

Допринос овог рада је и у томе што смо користили историјско-системски приступ и историјске компаративне методе у разматрању историјских процеса, догађаја и феномена који се одвијају у животу руске државе и повезани су са животом народа.

У процени догађаја из протеклих година (до 1917. године), током совјетског периода историје, аутори су уважавали принцип објективности, методу анализе садржаја, опште научне, историјске и етнографске методе.

Верујемо да ће ова студија продубити знање и разумевање ситуације у области националних односа, формирање погледа на свет и националног идентитета, идентификујући многе теоријске ставове за предвиђање развоја националних односа у руском друштву, развоју и усвајању правилних концепата у разним областима националне политике.

КљУчНЕ РЕчИ: национални односи; национална политика; етнополитички процеси.

Овај чланак је објављен и дистрибуира се под лиценцом Creative Commons Ауторство-Некомерцијално Међународна 4.0 (CC BY-NC 4.0 |

https://creativecommons.org/licenses/by-nc/4.0/).

This paper is published and distributed under the terms and conditions of the Creative Commons Attribution-NonCommercial International 4.0 licence (CC BY-NC 4.0 | https://creativecommons.org/licenses/by-nc/4.0/). 